\title{
New Coleoptera records for New Brunswick, Canada: Kateretidae, Nitidulidae, Cerylonidae, Endomychidae, Coccinellidae, and Latridiidae
}

\author{
Reginald P. Webster', Jon D. Sweeney', Ian DeMerchant' \\ I Natural Resources Canada, Canadian Forest Service - Atlantic Forestry Centre, 1350 Regent St., P.O. Box \\ 4000, Fredericton, NB, Canada E3B 5P7 \\ Corresponding author: Reginald Webster (reginaldwebster@rogers.com) \\ Academic editor: R. Anderson | Received 21 December 2011 | Accepted 21 February 2012 | Published 4 April 2012 \\ Citation: Webster RP, Sweeney JD, DeMerchant I (2012) New Coleoptera records for New Brunswick, Canada: \\ Kateretidae, Nitidulidae, Cerylonidae, Endomychidae, Coccinellidae, and Latridiidae. In: Anderson R, Klimaszewski \\ J (Eds) Biodiversity and Ecology of the Coleoptera of New Brunswick, Canada. ZooKeys 179: 193-214. doi: 10.3897/ \\ zookeys.179.2581
}

\begin{abstract}
We report 20 new species records for the Coleoptera fauna in New Brunswick, Canada, five of which are new records for the Maritime provinces, including one species that is new for Canada. One species of Kateretidae, Kateretes pusillus (Thunberg) is newly recorded for New Brunswick and the Maritime provinces. Stelidota octomaculata (Say), Phenolia grossa (Fabricius), and Cryptarcha strigatula Parsons of the family Nitidulidae are added to the faunal list of New Brunswick; the latter species is new to the Maritime provinces. Two species of Cerylonidae, Philothermus glabriculus LeConte and Cerylon unicolor (Ziegler), are reported for the first time for New Brunswick. Philothermus glabriculus is new for the Maritime provinces. Two species of Endomychidae, Hadromychus chandleri Bousquet and Leschen and Danae testacea (Ziegler) are newly recorded for New Brunswick. Three species of Coccinelidae, Stethorus punctum punctum (LeConte), Naemia seriata seriata Melsheimer, and Macronaemia episcopalis (Kirby) are added to the provincial list. Macronaemia episcopalis (Kirby) is a species new to the Maritime provinces. Nine species of Latridiidae, Cartodere nodifer (Westwood), Dienerella ruficollis (Marsham), Enicmus aterrimus Motschulsky, Enicmus fictus Fall, Encimus histrio Jay and Tomlin, Lathridius minutus (Linnaeus), Stephostethus productus Rosenhauer, Corticaria elongata (Gyllenhal), and Corticarina longipennis (LeConte) are newly recorded for New Brunswick. Stephostehus productus is newly recorded from Canada. Collection and habitat data are presented for all these species.
\end{abstract}

Copyright Her Majesty the Queen in Right of Canada. This is an open access article distributed under the terms of the Creative Commons Attribution License 3.0 (CC-BY), which permits unrestricted use, distribution, and reproduction in any medium, provided the original author and source are credited. 


\section{Keywords}

Cerylonidae, Coccinellidae, Endomychidae, Kateretidae, Latridiidae, Nitidulidae, new records, Canada, New Brunswick

\section{Introduction}

This paper treats new records from New Brunswick, Canada of the Coleoptera families Kateretidae, Nitidulidae, Cerylonidae, Endomychidae, Coccinellidae, and Latridiidae. The fauna of these families from New Brunswick and the Maritime provinces (New Brunswick, Nova Scotia, and Prince Edward Island) was recently treated by Majka and McCorquodale (2006), Majka and Robinson (2009) (Coccinellidae), Majka (2007), Majka (2009) (Endomychidae), Majka et al. (2008) (Kateretidae and Nitidulidae), Majka et al. (2009) (Latridiidae), and Majka and Langor (2011) (Cerylonidae). Intensive sampling in New Brunswick by the first author since 2003 and records obtained from a study to develop a general attractant for the detection of invasive Cerambycidae species have yielded additional new provincial records in the above families. This paper reports on these new records and provides a brief synopsis of each family.

\section{Methods and conventions}

The following records are based on specimens collected during a general survey by the first author to document the Coleoptera fauna of New Brunswick and from by-catch samples obtained during a study to develop a general attractant for the detection of invasive species of Cerambycidae. Additional records were obtained from specimens contained in the collection of the Natural Resources Canada, Canadian Forest Service - Atlantic Forestry Centre, Fredericton, New Brunswick.

\section{Collection methods}

Various methods were employed to collect the specimens and details are outlined in Webster et al. (2009, Appendix). Many specimens were also collected from 12-unit Lindgren funnel traps set in various forest habitats in New Brunswick between 2008 and 2011. These traps visually mimic tree trunks and are often effective for sampling species of Coleoptera that live in microhabitats associated with standing trees (Lindgren 1983). See Webster et al. (in press) for details of the methods used to deploy Lindgren 12-funnel traps and for sample collection. A description of the habitat was recorded for all specimens collected during this survey. Locality and habitat data are presented exactly as on labels for each record. This information, as well as additional collecting notes, is summarized and discussed in the collection and habitat data section for each species. 


\section{Distribution}

Distribution maps, created using ArcMap and ArcGIS, are presented for each species in New Brunswick. Every species is cited with its currently known distribution in Canada and Alaska, using abbreviations for the state, provinces, and territories. New records for New Brunswick are indicated in bold under Distribution in Canada and Alaska. The following abbreviations are used in the text:

\begin{tabular}{ll|ll}
\hline AK & Alaska & MB & Manitoba \\
\hline YT & Yukon Territory & ON & Ontario \\
\hline NT & Northwest Territories & QC & Quebec \\
\hline NU & Nunavut & NB & New Brunswick \\
\hline BC & British Columbia & PE & Prince Edward Island \\
\hline AB & Alberta & NS & Nova Scotia \\
\hline SK & Saskatchewan & NF \& LB & Newfoundland and Labrador* \\
\hline
\end{tabular}

*Newfoundland and Labrador are each treated separately under the current Distribution in Canada and Alaska.

Acronyms of collections examined or where voucher specimens reside are as follows:

AFC Atlantic Forestry Centre, Natural Resources Canada, Canadian Forest Service, Fredericton, New Brunswick, Canada

CNC Canadian National Collection of Insects, Arachnids and Nematodes, Agriculture and Agri-Food Canada, Ottawa, Ontario, Canada

MTC Martin Turgeon Collection, Saint Basil, New Brunswick, Canada

NBM New Brunswick Museum, Saint John, New Brunswick, Canada

RWC Reginald P. Webster Collection, Charters Settlement, New Brunswick, Canada

\section{Results}

\section{Species accounts}

All records below are species newly recorded for New Brunswick, Canada. Species followed by ${ }^{* *}$ are newly recorded from the Maritime provinces of Canada. Species followed by ${ }^{* * *}$ are newly recorded for Canada.

\section{Family Kateretidae Kirby, 1837}

The Kateretidae (the short-winged flower beetles) are phytophagous both as larvae and adults (Habeck 2002a). Larvae develop in seed capsules, and adults feed on flower petals and pollen. The Kateretidae (including Nitidulidae) of New Brunswick was reviewed by Majka et al. (2008). Four species were recorded for the province, including Brachypterus 
urticae (Fabricius), Heterhelus abdominalis (Erichson), and Heterhelus sericans (LeConte), which were newly reported for New Brunswick. Here, we newly record Kateretes pusillus (Thunberg) for New Brunswick and the Maritime provinces (see Table 1).

Table I. Species of Kateretidae, Cerylonidae, Endomychidae, and Latridiidae known from New Brunswick, Canada.

\begin{tabular}{|c|}
\hline Kateretidae Kirby \\
\hline Brachypterolus pulicarius (Linnaeus) \\
\hline Brachypterus urticae (Fabricius) \\
\hline Heterhelus abdominalis (Erichson) \\
\hline Heterhelus sericans (LeConte) \\
\hline Kateretes pusillus (Thunberg)** \\
\hline Family Cerylonidae Billberg \\
\hline Subfamily Ceryloninae Billberg \\
\hline Cerylon castaneum Say \\
\hline Cerylon unicolor (Ziegler)* \\
\hline Philothermus glabriculus LeConte** \\
\hline Family Endomychidae Leach \\
\hline Subfamily Endomychinae Leach \\
\hline Endomychus biguttatus Say \\
\hline Subfamily Epipocinae Gorham \\
\hline Hadromychus chandleri Bousquet \& Leschen* \\
\hline Subfamily Leiestinae Thomson \\
\hline Phymaphora pulchella Newman \\
\hline Subfamily Lycoperdininae Bromhead \\
\hline Lycoperdina ferruginea LeConte \\
\hline Mycetina perpulchra (Newman) \\
\hline Subfamily Stenotarsinae Chapuis \\
\hline Danae testacea (Ziegler)* \\
\hline Family Latridiidae Erichson \\
\hline Subfamily Latridiinae Erichson \\
\hline Cartodere (Cartodere) constrcta (Gyllenhal) \\
\hline
\end{tabular}

\begin{tabular}{l}
\hline Cartodere (Aridius) nodifer (Westwood)* \\
\hline Dienerella argus (Reitter) \\
\hline Dienerella ruficollis (Marsham)* \\
\hline Enicmus aterrimus Motschulsky* \\
\hline Enicmus fictus Fall** \\
\hline Enicmus histrio Joy \& Tomlin* \\
\hline Enicmus tenuicornis LeConte \\
\hline Lathridius consimilis (Mannerheim) \\
\hline Lathridius minutus (Linnaeus)* \\
\hline Stephostethus breviclavis (Fall) \\
\hline Stephostethus litratus (LeConte) \\
\hline Stephostethus productus Rosenhauer*** \\
\hline Thes bergrothi (Reitter) \\
\hline Subfamily Cortcarinae Curtis \\
\hline Corticaria elongata (Gyllenhal)* \\
\hline Corticaria ferruginea Marsham \\
\hline Corticaria impressa (Olivier) \\
\hline Corticaria rubripes Mannerheim \\
\hline Corticaria saginata Mannerheim \\
\hline Corticarina cavicollis (Mannerheim) \\
\hline Corticarina longipennis (LeConte)* \\
\hline Corticarina minuta (Fabricius) \\
\hline Cortinicara gibbosa (Herbst) \\
\hline Melanophthalma helvola Motschulsky \\
\hline Melanophthalma inermis Motschulsky \\
\hline Melanophthalma picta (LeConte) \\
\hline
\end{tabular}

Notes: ${ }^{*}$ New to province, ${ }^{* *}$ New to Maritime provinces, ${ }^{* * *}$ New to Canada.

\section{Kateretes pusillus (Thunberg, 1794)**}

http://species-id.net/wiki/Kateretes_pusillus

Map 1

Material examined. New Brunswick, Restigouche Co., Wild Goose Lake, $47.8539^{\circ} \mathrm{N}$, 68.3219² W, 7.VI.2011, 20.VI.2011, R. Webster \& M. Turgeon, lake margin, Carex marsh, treading Carex (21, AFC, MTC, NBM, RWC); Kedgwick Road at Fog Brook, $47.8367^{\circ} \mathrm{N}, 67.8739^{\circ} \mathrm{W}, 21 . \mathrm{VI} .2011$, R. P. Webster, Carex marsh near brook, treading Carex (2, NBM, RWC). 
Collection and habitat data. Adults of this northern species were collected by treading (forcing emergent vegetation into water) Carex in Carex marshes along a lake margin and a brook. At both sites where this species was found, Carex was covered with pollen. Adults were captured during June. Specimens of this species in the Carr collection in the $\mathrm{CNC}$ were collected by sweeping or sieving sedges in beaver (Castor canadensis Kuhl.) ponds, marshes, bogs, dried boggy areas, small muskegs, sedge marshes, swamps, in sphagnum and moss at the edge of a sedge marsh, in wash-up along a river, and by sifting willow (Salix)/poplar (Populus) leaves on a slope around a marsh (Anthony Davies, personal communication).

Distribution in Canada and Alaska. AK, NT, AB, SK, ON, QC, NB (McNamara 1991b).

\section{Family Nitidulidae Latreille, 1802}

The Nitidulidae (the sap beetles) is a large family of mostly saprophagous and mycetophagous species (Habeck 2002b) with many taxa found in decaying fruit, in fermenting plant juices and sap, on fungal sporocarps, and others on flowers. Nitidula sp. and Omosita sp. are found in carrion, and a few species are minor stored-product pests (Habeck 2002b). The Nitidulidae (as well as Kateretidae) of New Brunswick was reviewed by Majka et al. (2008). Forty-two species were recorded for the province, 28 were newly reported. Here, we report three additional species from the province. See Majka et al. (2008) for a list of the other Nitidulidae species known from New Brunswick.

\section{Subfamily Nitidulinae Latreille, 1802}

\section{Stelidota octomaculata (Say, 1825)}

http://species-id.net/wiki/Stelidota_octomaculata

Map 2

Material examined. New Brunswick, Queens Co., Cranberry Lake P.N.A (Protected Natural Area), $46.1125^{\circ} \mathrm{N}, 65.6075^{\circ} \mathrm{W}, 2 . I X .2009$, R. Webster \& M.-A. Giguère, old red oak forest, in nest of black Formica species (mound building species) (1, RWC); same locality data and forest type, 31.VIII-15.IX.2011, C. Hughes \& R. P. Webster, Lindgren funnel traps (2, RWC).

Collection and habitat data. Stelidota octomaculata has been reported from decaying fruit and fungi, coral fungi (Downie and Arnett 1996), gilled mushrooms, decaying pigs, and from pitfall traps deployed in a hardwood forest (Majka and Cline 2006). One specimen from New Brunswick was found in a Formica ant nest in an old red oak (Quercus rubra L.) stand; two others were captured in Lindgren funnel traps in the same forest. Adults were collected during September.

Distribution in Canada and Alaska. ON, QC, NB, NS (McNamara 1991b; Majka and Cline 2006). 


\section{Phenolia grossa (Fabricius, 1801)}

http://species-id.net/wiki/Phenolia_grossa

Map 3

Material examined. New Brunswick, Carleton Co., Meduxnekeag Valley Nature Preserve, $46.1940^{\circ} \mathrm{N}, 67.6801^{\circ} \mathrm{W}, 12 . \mathrm{IX} .2008$, R. P. Webster, mixed forest, in Laetiporus sulphureus (3, RWC); same locality but $46.1887^{\circ} \mathrm{N}, 67.6735^{\circ} \mathrm{W}, 13 . \mathrm{VI} .2010$, R. P. Webster, hardwood forest, in Laetiporus sulphureus (8, NBM, RWC). Queens Co., Cranberry Lake P.N.A, $46.1125^{\circ} \mathrm{N}, 65.6075^{\circ} \mathrm{W}, 7 . V I-22 . V I .2011$, M. Roy \& V. Webster, old red oak forest, Lindgren funnel trap (1, NBM); same locality data and forest type, 4.VIII.2011, 18.VIII.2011, R. P. Webster, in Laetiporus sulphureus (5, AFC, NBM, RWC).

Collection and habitat data. Majka and Cline (2006) reported this species mostly from coniferous forests in Nova Scotia and from one hardwood stand. Adults were reported from decaying red maple (Acer rubrum L.) and decomposing fungi. In New Brunswick, adults were collected from Laetiporus sulphureus (Fr.) Murr. (chicken mushroom) in a hardwood forest with sugar maple (Acer saccharum Marsh.), white ash (Fraxinus americana L.), and American beech (Fagus grandifolia Ehrh.) and in an old red oak forest. One individual was captured in a Lindgren funnel trap deployed in an old red oak stand. Adults were collected during June, August, and September.

Distribution in Canada and Alaska. ON, QC, NB, NS (McNamara 1991b; Majka and Cline 2006).

\section{Subfamily Cryptarchinae Thomson, 1859 \\ Tribe Cryptarchini Thomson, 1859}

Cryptarcha strigatula Parsons, 1938**

http://species-id.net/wiki/Cryptarcha_strigatula

Map 4

Material examined. New Brunswick, Queens Co., Cranberry Lake P.N.A, $46.1125^{\circ} \mathrm{N}$, 65.6075 ${ }^{\circ} \mathrm{W}, 7-22 . V I .2011$, M. Roy \& V. Webster, mature red oak forest, Lindgren funnel traps (2, RWC). Charters Settlement, $45.8395^{\circ} \mathrm{N}, 66.7391^{\circ} \mathrm{W}, 20 . \mathrm{VII} .2006$, 1.VIII.2007, R. P. Webster, mixed forest, m.v. light (2, RWC).

Collection and habitat data. This species was captured in Lindgren funnel traps deployed in an old red oak forest and at a mercury-vapor light near a mixed forest. Adults were collected during June, July, and August.

Distribution in Canada and Alaska. ON, QC, NB. There are two specimens in the CNC from Canada with the following data: Ont: Leeds County, Leeds and Lansdowne Township, 17.VIII.1992, Quercus alba under bark; Que: Co. Iberville, Rivière du Sud, 30.VII.1975, N. Doiron, CH308 (Anthony Davies, personal communication). 


\section{Family Cerylonidae Billberg, 1820}

North American species of Cerylonidae (the minute bark beetles) were revised by Lawrence and Stephan (1975). Nineteen species were recorded for North America (Lawrence and Stephan 1975), seven from Canada, and only Cerylon castaneum Say from New Brunswick (Campbell 1991a). Majka and Langor (2011) reviewed the Cerylonidae of Atlantic Canada but did not report any additional species for New Brunswick. Adults are found under bark, in leaf litter, or in rotten wood and probably feed on fungi (Campbell 1991b; Thomas 2002). The adventive Murmidius ovalis (Beck) occurs in stored products (Lawrence and Stephan 1975). Here, we report two species of Cerylonidae that are new for New Brunswick (Table 1). Philothermus glabriculus LeConte is newly recorded for the Maritime provinces.

\section{Subfamily Ceryloninae Billberg, 1820}

\section{Philothermus glabriculus LeConte, 1863**}

http://species-id.net/wiki/Philothermus_glabriculus

Map 5

Material examined. New Brunswick, Carleton Co., Jackson Falls, Bell Forest, $46.2200^{\circ} \mathrm{N}, 67.7231^{\circ} \mathrm{W}, 4-12 . \mathrm{VI} .2008$, R. P. Webster, mature hardwood forest, Lindgren funnel traps (2, AFC, NBM). Queens Co., Cranberry Lake P.N.A., $46.1125^{\circ} \mathrm{N}, 65.6075^{\circ} \mathrm{W}, 25 . \mathrm{VI}-1$. VII.2009, R. Webster \& M.-A. Giguère, mature red oak forest, Lindgren funnel trap (1, RWC); same locality and habitat data, 7-22. VI.2011, 29.VI-7.VII.2011, 7-13.VII.2011, M. Roy \& V. Webster, Lindgren funnel traps (7, AFC, NBM, RWC). Sunbury Co., Acadia Research Forest, $45.9866^{\circ} \mathrm{N}$, 66.3841 ${ }^{\circ} \mathrm{W}, 24-30 . V I .2009$, R. Webster \& M.-A. Giguère, mature (110 year-old) red spruce forest with scattered red maple and balsam fir, Lindgren funnel trap (1, RWC). York Co., $15 \mathrm{~km} \mathrm{~W}$ of Tracy off Rt. 645, 45.6848 $\mathrm{N}, 66.8821^{\circ} \mathrm{W}, 7-14$. VII.2010, R. Webster \& C. MacKay, old red pine forest, Lindgren funnel trap (1, RWC); $14 \mathrm{~km}$ WSW of Tracy, S of Rt. $645,45.6741^{\circ} \mathrm{N}, 66.8661^{\circ} \mathrm{W}, 16-30$. VI.2010, R. Webster \& C. MacKay, old mixed forest with red and white spruce, red and white pine, balsam fir, eastern white cedar, red maple, and Populus sp., Lindgren funnel trap (1, AFC).

Collection and habitat data. Philothermus glabriculus was collected in various forest types in New Brunswick, including a mature hardwood forest with American beech, sugar maple, white ash, a mature red oak forest, a mature red spruce (Picea rubens Sarg.) forest, an old red pine (Pinus resinosa Ait.) forest, and an old mixed forest. Adults were captured in Lindgren funnel traps during June and July.

Distribution in Canada and Alaska. ON, QC, NB (Campbell 1991a). 


\section{Cerylon unicolor (Ziegler, 1845)}

http://species-id.net/wiki/Cerylon_unicolor

Map 6

Material examined. New Brunswick, Carleton Co., Jackson Falls, Bell Forest, $46.2200^{\circ} \mathrm{N}, 67.7231^{\circ} \mathrm{W}, 6 . \mathrm{V} .2007$, R. P. Webster, mature hardwood forest, on fleshy polypore (bracket) fungi on dead standing beech (1, RWC); same locality and forest type but 1-8.VI.2009, 16-21.VI.2009, 21-28.VI.2009, 7-14.VII.2009, R. Webster \& M.-A. Giguère, Lindgren funnel traps (4, AFC, RWC); Meduxnekeag Valley Nature Preserve, $46.1907^{\circ} \mathrm{N}, 67.6740^{\circ} \mathrm{W}, 7 . V I .2007$, R. P. Webster, hardwood forest, under bark of sugar maple $\log (1, \mathrm{RWC})$. Charlotte Co., $10 \mathrm{~km} \mathrm{NW}$ of New River Beach, $45.2110^{\circ} \mathrm{N}, 66.6170^{\circ} \mathrm{W}, 15-29 . V I .2010$, R. Webster \& C. MacKay, old growth eastern white cedar forest, Lindgren funnel trap (1, AFC). Queens Co., Cranberry Lake P.N.A., $46.1125^{\circ} \mathrm{N}, 65.6075^{\circ} \mathrm{W}, 5-11 . V I .2009,25 . V I-1 . V I I .2009$, R. Webster \& M.-A. Giguère, mature red oak forest, Lindgren funnel trap (2, NBM, RWC). Restigouche Co., Kedgwick Forks, $47.9085^{\circ} \mathrm{N}, 67.9057^{\circ} \mathrm{W}$, 22.VI.2010, river margin, in flood debris (1, NBM). Sunbury Co., Portobello Creek N.W.A., Maugerville, $45.8990^{\circ} \mathrm{N}, 66.4200^{\circ} \mathrm{W}, 28 . V I .2004$, R. P. Webster, silver maple swamp, under bark of $\log (1, \mathrm{RWC})$; Acadia Research Forest, $45.9866^{\circ} \mathrm{N}, 66.3841^{\circ} \mathrm{W}, 16-24 . \mathrm{VI} .2009$, 24-30.VI.2009, R. Webster \& M.-A. Giguère, mature (110 year-old) red spruce forest with scattered red maple and balsam fir, Lindgren funnel traps (5, AFC). York Co., Charters Settlement, $45.8188^{\circ} \mathrm{N}, 66.7460^{\circ} \mathrm{W}, 25$. VIII.2004, R. P. Webster, clear-cut, under bark of conifer stump (3, RWC); same locality but $45.8286^{\circ} \mathrm{N}$, $66.7365^{\circ} \mathrm{W}, 2 . \mathrm{VI} .2007$, R. P. Webster, mature red spruce forest, under bark of red spruce (1, RWC); $15 \mathrm{~km} \mathrm{~W}$ of Tracy off Rt. $645,45.6848^{\circ} \mathrm{N}, 66.8821^{\circ} \mathrm{W}, 15-21$. VI.2009, R. Webster \& M.-A. Giguère, old red pine forest, Lindgren funnel traps (2, AFC); $14 \mathrm{~km} \mathrm{WSW} \mathrm{of} \mathrm{Tracy,} \mathrm{S} \mathrm{of} \mathrm{Rt.} 645,45.6741^{\circ} \mathrm{N}, 66.8661^{\circ} \mathrm{W}, 10-26 . V .2010$, R. Webster \& C. MacKay, old mixed forest with red and white spruce, red and white pine, balsam fir, eastern white cedar, red maple, and Populus sp., Lindgren funnel trap (1, AFC).

Collection and habitat data. In Nova Scotia, this species was found in red spruce stands on Fomitopsis officinalis (Fr.) Bond. \& Sing., in an old-growth hemlock (Tsuga canadensis (L.) Carr.) forest, and in a mixed old-growth hemlock, black spruce (Picea mariana (Mill.) B.S.P.), and balsam fir (Abies balsamea (L.) Mill.) stand (Majka and Langor 2011). This species has been reported from under bark of various hardwood and conifer species, and on fungi, such as Bjerkandera adusta (Fr.) Kar. and Phellinus gilvus (Schw.) Pat. (Lawrence and Stephan 1975). In New Brunswick, Cerylon unicolor was collected from under bark of sugar maple, silver maple (Acer saccharinum L.), red spruce, and a conifer stump. One individual was sifted from flood debris along a river margin, another was found in fleshy polypore fungi on a dead, standing American beech tree. This species was also captured in Lindgren funnel traps deployed in hardwood forests with sugar maple and American beech, mixed forests, a mature red oak forest, an old red pine forest, a mature red spruce 


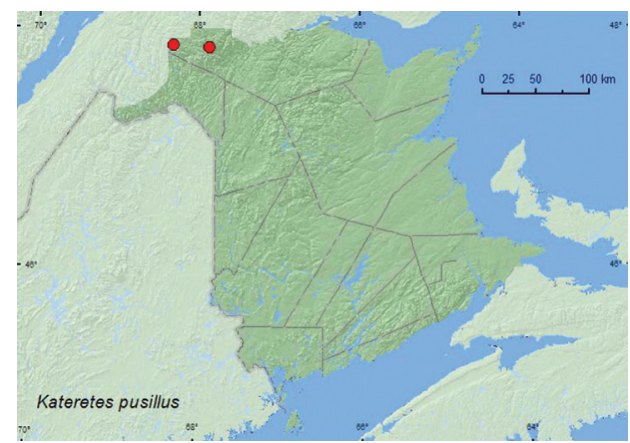

Map I. Collection localities in New Brunswick, Canada of Kateretes pusillus.

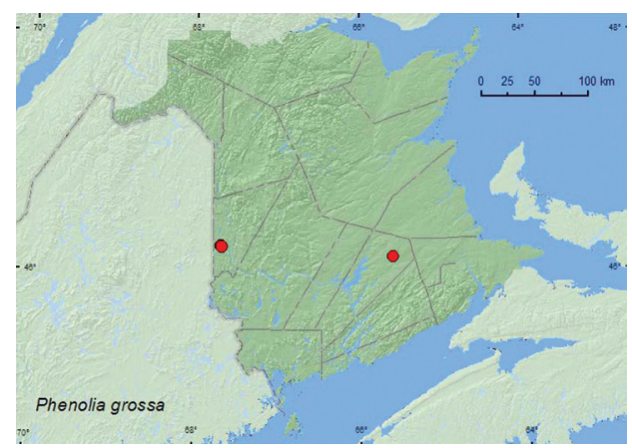

Map 3. Collection localities in New Brunswick, Canada of Phenolia grossa.

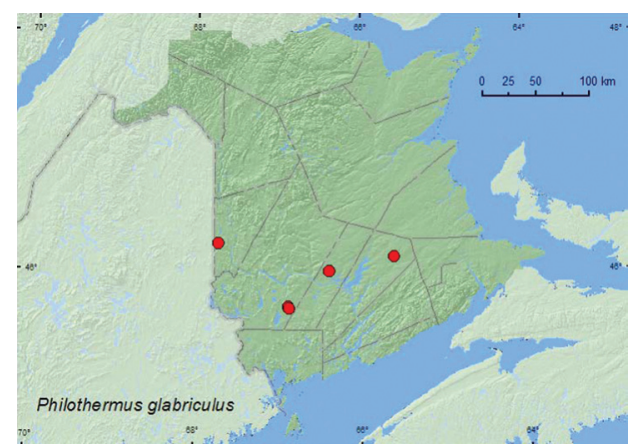

Map 5. Collection localities in New Brunswick, Canada of Philothermus glabriculus.

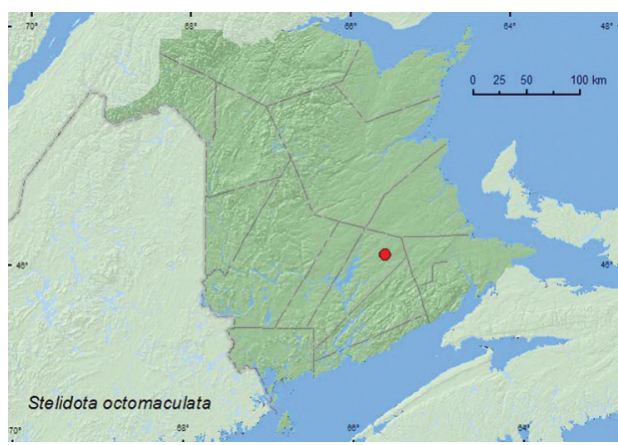

Map 2. Collection localities in New Brunswick, Canada of Stelidota octomaculata.

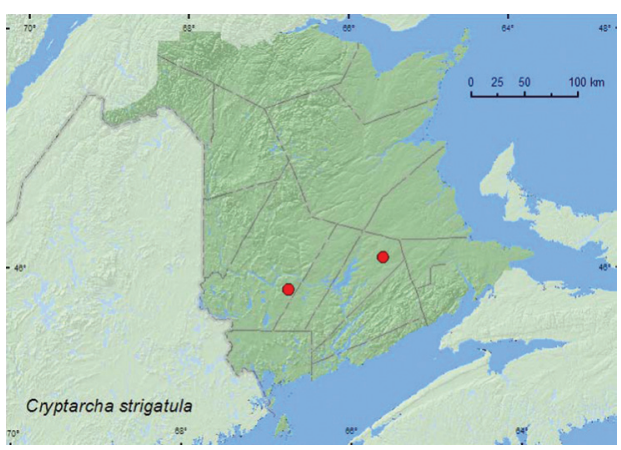

Map 4. Collection localities in New Brunswick, Canada of Cryptarcha strigatula.

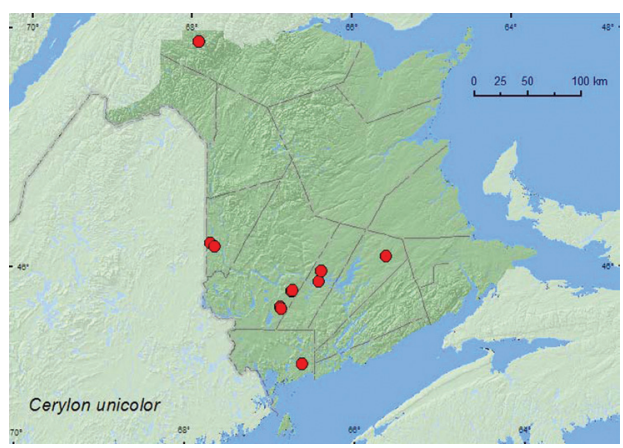

Map 6. Collection localities in New Brunswick, Canada of Cerylon unicolor.

forest, and an old eastern white cedar (Thuja occidentalis L.) forest. Adults were captured during May, June, and July.

Distribution in Canada and Alaska. NT, BC, AB, ON, QC, NB, NS, NF (Campbell 1991a; Majka and Langor 2011). 


\section{Family Endomychidae Leach, 1815}

The Endomychidae (handsome fungus beetles) are found in subcortical fungi, soft polypores, fleshy basidiomycetes, and various molds and mildews or are specialists on puffballs (Lycoperdina ferruginea LeConte) (Skelley and Leschen 2002). The Endomychidae (and Erotylidae) of the Maritime provinces were reviewed by Majka (2007). Phymatphora pulchella Newman and Rhanidea unicolor (Ziegler) (Endomychidae) were reported from the province for the first time. However, the determination of $R$. unicolor was in error and was a specimen of Lycoperdina ferruginea LeConte, a species new to New Brunswick (Majka 2009). Rhanidea unicolor was, therefore, removed from the faunal list of the province. Majka (2007) discussed the fungal associations of members of this family from the Maritime provinces and the impact that forest management practices may have on the communities of forest fungi and the associated beetle species dependent on these fungi. Four species of Endomychidae were reported from New Brunswick by Majka $(2007,2009)$. Here, we add two species to the faunal list of New Brunswick (Table 1).

\section{Subfamily Epipocinae Gorham, 1873}

Hadromychus chandleri Bousquet \& Leschen, 2002

http://species-id.net/wiki/Hadromychus_chandleri Map 7

Material examined. New Brunswick, Carleton Co., Jackson Falls, Bell Forest, $46.2200^{\circ} \mathrm{N}, 67.7231^{\circ} \mathrm{W}, 4-12 . V I .2008,12-19 . V I .2008$, R. P. Webster, mature hardwood forest, Lindgren funnel traps (5, NBM, RWC); same locality and habitat data, 28.IV-9.V.2009, 9-14.V.2009, 14-20.V.2009, 21-28.VI.2009, R. Webster \& M.-A. Giguère, mature hardwood forest, Lindgren funnel traps (8, AFC, RWC). Queens Co., Cranberry Lake P.N.A., $46.1125^{\circ} \mathrm{N}, 65.6075^{\circ} \mathrm{W}, 12-21 . V .2009,21-27 . V .2009$, 27.V-5.VI.2009, R. Webster \& M.-A. Giguère, old red oak forest, Lindgren funnel traps (5, AFC); same locality data and forest type, 25.V-7.VI.2011, M. Roy \& V. Webster, Lindgren funnel trap (1, NBM). Restigouche, Co., Dionne Brook P.N.A., $47.9030^{\circ} \mathrm{N}, 68.3503^{\circ} \mathrm{W}, 31 . \mathrm{V}-15 . \mathrm{VI} .2011$, M. Roy \& V. Webster, old-growth northern hardwood forest, Lindgren funnel traps (3, AFC, NBM); same locality and collectors but $47.9064^{\circ} \mathrm{N}, 68.3441^{\circ} \mathrm{W}, 31 . \mathrm{V}-15 . \mathrm{VI} .2011,27 . \mathrm{VI}-14 . \mathrm{VII} .2011$, old-growth white spruce and balsam fir forest (26, AFC, NBM, RWC). Sunbury Co., Acadia Research Forest, $45.9866^{\circ} \mathrm{N}, 66.3841^{\circ} \mathrm{W}, 28 . I V-8 . V .2009,13-19 . V .2009,19-25 . V .2009,2-9$. VI.2009, 24-30.VI.2009, R. Webster \& M.-A. Giguère, mature (110 year-old) red spruce forest with scattered red maple and balsam fir, Lindgren funnel traps (6, AFC, RWC). York Co., $15 \mathrm{~km} \mathrm{~W}$ of Tracy off Rt. 645, 45.6848 N, 66.8821 ${ }^{\circ} \mathrm{W}, 4-11 . V .2009$, 11-19.V.2009, R. Webster \& M.-A. Giguère, old red pine forest, Lindgren funnel traps (2, AFC, RWC); $14 \mathrm{~km} \mathrm{WSW} \mathrm{of} \mathrm{Tracy,} \mathrm{S} \mathrm{of} \mathrm{Rt.} 645,45.6741^{\circ} \mathrm{N}, 66.8661^{\circ} \mathrm{W}, 26 . \mathrm{IV}$ 10.V.2010, 10-26.V.2010, 26.V-2.VI.2010, R. Webster \& C. MacKay, old mixed forest 
with red and white spruce, red and white pine, balsam fir, eastern white cedar, red maple, and Populus sp., Lindgren funnel traps (8, AFC); Charters Settlement, $45.8395^{\circ} \mathrm{N}$, $66.7391^{\circ} \mathrm{W}, 1-5 . V I .2011$, R. P. Webster, mixed forest, flight intercept trap (1, NBM).

Collection and habitat data. Little is known about the habitat requirements of $H$. chandleri. All (64) specimens from New Brunswick were captured in Lindgren funnel traps, which visually mimic tree trunks and are often effective for sampling species of Coleoptera that live in microhabitats associated with standing trees (Lindgren 1983). This species may likely live in microhabitats associated with standing trees. Specimens of this species were collected from a various forest types in New Brunswick. Adults were collected in a mature hardwood forest, an old-growth northern hardwood forest with sugar maple and yellow birch (Betula alleghaniensis Britt.), an old red oak forest, a mature red spruce forest, an old red pine forest, an old-growth white spruce (Picea glauca (Moench) Voss) and balsam fir forest, and old mixed forests. Most adults were captured in an old-growth white spruce and balsam fir forest (boreal forest) in northwestern New Brunswick. This species is likely a northern and boreal faunal component. Adults were collected during April, May, June, and July.

Distribution in Canada and Alaska. ON, QC, NB, NS (Bousquet and Leschen 2002). The type series of this species consisted of seven specimens originating from New Hampshire, Nova Scotia, Ontario, and Quebec (Bousquet and Leschen 2002). Majka (2007) reported five additional specimens from Nova Scotia. Majka (2007) suggested that $H$. chandleri may be the rarest North American endomychid species. However, 64 specimens of this species were collected in New Brunswick between 2008 and 2011, indicating that this species may be more common, at least locally, than previously thought. All specimens from New Brunswick were captured in Lindgren funnel traps, and those reported by Majka (2007) from Nova Scotia were caught in flight-intercept traps, further suggesting that more specialized sampling methods are required to document the occurrence of this species. This species was most abundant in an old-growth boreal forest with white spruce and balsam fir.

\section{Subfamily Stenotarsinae Chapius, 1876}

\section{Danae testacea (Ziegler, 1844)}

http://species-id.net/wiki/Danae_testacea

Map 8

Material examined. New Brunswick, Queens Co., Cranberry Lake P.N.A., $46.1125^{\circ} \mathrm{N}, 65.6075^{\circ} \mathrm{W}, 14-19$. VIII.2009, R. Webster \& M.-A. Giguère, old red oak forest, Lindgren funnel trap (1, RWC). York Co., $15 \mathrm{~km} \mathrm{~W}$ of Tracy off Rt. 645, $45.6848^{\circ} \mathrm{N}, 66.8821^{\circ} \mathrm{W}, 29 . V I-7 . V I I I .2009$, R. Webster \& M.-A. Giguère, old red pine forest, Lindgren funnel trap (1, RWC).

Collection and habitat data. Danae testacea was captured in Lindgren funnel traps in an old red oak forest and an old red pine forest. Both individuals of this species 
were captured during August. The specimen reported from Nova Scotia was found in an old-growth hardwood stand, and Majka (2007) suggested that this species may be associated with old-growth hardwood forests.

Distribution in Canada and Alaska. ON, QC, NB, NS (Campbell 1991b).

\section{Family Coccinellidae Latreille, 1807}

Majka and McCorquodale (2006) reviewed the Coccinellidae (the lady beetles) of the Maritime provinces. Later Majka and Robinson (2009) reviewed the Hyperaspis and Brachiacantha species in the Maritime provinces and provided keys to species. Thirtynine species were reported from New Brunswick by Majka and McCorquodale (2006), but no new provincial records were reported. Three additional species are reported here, including Macronaemia episcopalis (Kirby), a species new to the Maritime provinces. See Majka and McCorquodale (2006) for a list of the other species of Coccinelidae known from New Brunswick.

\section{Subfamily Symninae}

Stethorus punctum punctum (LeConte, 1852)

http://species-id.net/wiki/Stethorus_punctum_punctum Map 9

Material examined. New Brunswick, Charlotte Co., St. Andrews, $45.0751^{\circ} \mathrm{N}$, $67.0374^{\circ} \mathrm{W}, 25$. VIII.2009, R. P. Webster, sea beach, sweeping foliage (1, RWC). Sunbury Co., Lakeville Corner, $45.9013^{\circ} \mathrm{N}, 66.2565^{\circ} \mathrm{W}, 27$. VIII.2006, R. P. Webster, silver maple forest, on corncobs (1, RWC).

Collection and habitat data. This species was collected by sweeping foliage on a sea beach and sifting debris from a pile of corncobs in a silver maple (Acer saccharinum L.) forest. The two adults were captured during August.

Distribution in Canada and Alaska. AB, SK, ON, QC, NB, NS (McNamara 1991a).

\section{Subfamily Coccinellinae}

Naemia seriata seriata Melsheimer, 1847

http://species-id.net/wiki/Naemia_seriata_seriata

Map 10

Material examined. New Brunswick, Saint John Co., Dipper Harbour, $45.1169^{\circ} \mathrm{N}$, $66.3771^{\circ} \mathrm{W}, 12 . \mathrm{IX} .2006$, R. P. Webster, salt marsh, on flowers of seaside golden- 
rod (9 (many others observed), RWC); Chance Harbour off Cranberry Head Road, $45.1355^{\circ} \mathrm{N}, 66.3436^{\circ} \mathrm{W}, 30 . \mathrm{V} .2006$, R. P. Webster, barrier beach, sweeping foliage of Leucanthemum vulgare Lam. (1, RWC); black beach, $45.1539^{\circ} \mathrm{N}, 66.2282^{\circ} \mathrm{W}$, 11.VII.2008, R. P. Webster, sea beach, sweeping foliage (1, RWC).

Collection and habitat data. Adults were taken by sweeping foliage of ox-eye daisy (Leucanthemem vulgare Lam.) on a barrier beach, sweeping foliage on a sea beach, and sweeping flowers of seaside goldenrod (Solidago sempervirens L.) in a salt marsh. Adults were taken during late May, July, and September.

Distribution in Canada and Alaska. NB, NS (Majka and McCorquodale 2006). Majka and McCorquodale (2006) considered the Nova Scotia population as significantly disjunct from the remainder of its range (from southern Maine (Dearborn and Donahue 1993) to Central America (Gordon 1985)), and considered Nova Scotia at the northern limit of its environmental tolerances. This species is likely more widely distributed along the coast than originally thought and the distributional gaps may be the result of insufficient sampling in intervening areas.

\section{Macronaemia episcopalis (Kirby, 1837)**}

http://species-id.net/wiki/Macronaemia_episcopalis Map 11

Material examined. New Brunswick, Saint John Co., Dipper Harbour, $45.1169^{\circ} \mathrm{N}$, $66.3771^{\circ} \mathrm{W}, 7 . V .2006$, R. P. Webster, margin of salt marsh, in debris on $\log (7, \mathrm{RWC})$; same locality, 12.IX.2006, R. P. Webster, salt marsh, sweeping vegetation (3, NBM, RWC).

Collection and habitat data. Macronaemia episcopalis was collected from salt marshes during September by sweeping foliage and sifting debris on a log in early May. The latter site was probably an overwintering site.

Distribution in Canada and Alaska. AK, YK, NT, BC, AB, SK, MB, ON, QC, NB (McNamara 1991a). Gordon (1985) reported this species only as far east as western Quebec.

\section{Family Latridiidae Erichson, 1842}

Andrews (2002) provided a general review of the Latridiidae (the minute brown scavenger beetles) of North America. Both adults and larvae feed on fungal conidia of Myxomycetes and can be found in leaf litter (Latridiinae) or by sweeping dead vegetation (Corticariinae). Some species occur in stored products (Andrews 2002). Bousquet (1991) reported 55 species for Canada and only six species for New Brunswick. Majka et al. (2009) reviewed the Latridiidae of the Atlantic Canada, provided keys to the known species from the region, and added 11 species to the faunal list of New Brunswick. Here, we report nine additional species for the province, including Stephostehus productus Rosenhauer, which is new for Canada. 


\section{Subfamily Latridiinae Erichson, 1842}

Cartodere (Aridius) nodifer (Westwood, 1839)

http://species-id.net/wiki/Cartodere_nodifer

Map 12

Material examined. New Brunswick, Queens Co., Cranberry Lake P.N.A., $46.1125^{\circ} \mathrm{N}, 65.6075^{\circ} \mathrm{W}, 25 . \mathrm{VI}-1 . \mathrm{VII} .2009,21-28 . V I I .2009$, R. Webster \& M.A. Giguère, old red oak forest, Lindgren funnel traps (2, AFC, RWC). York Co., Charters Settlement, $45.8395^{\circ} \mathrm{N}, 66.7391^{\circ} \mathrm{W}, 26 . I X .2007$, 30.IX.2007, 5.X.2007, 11.X.2007, 18.X.2007, R. P. Webster, mixed forest, in decaying (mouldy) corncobs and cornhusks (9, RWC).

Collection and habitat data. This adventive species is associated with stored products and has been found in various habitats promoting the growth of molds, such as under bark, in vegetable refuse, haystacks, and leaf compost (Hatch 1962; Bousquet 1990). Specimens from New Brunswick were sifted from decaying moldy corncobs and cornhusks, and captured in Lindgren funnel traps deployed in an old red oak forest. Adults were captured during June, July, September, and October.

Distribution in Canada and Alaska. BC, MB, ON, QC, NB, NS, PE (Bousquet 1991; Majka et al. 2009).

Dienerella ruficollis (Marsham, 1802)

http://species-id.net/wiki/Dienerella_ruficollis

Map 13

Material examined. New Brunswick, Kings Co. Belle Isle (Bellisle Creek), II.18.1981 (no collector given), ex. bulk milk tank (20, AFC).

Collection and habitat data. A large series of this adventive Palaearctic species was collected from a bulk milk tank.

Distribution in Canada and Alaska. BC, ON, QC, NB, NS, NF (Bousquet 1991).

Enicmus aterrimus Motschulsky, 1866

http://species-id.net/wiki/Enicmus_aterrimus

Map 14

Material examined. New Brunswick, Carleton Co., Jackson Falls, Bell Forest, $46.2200^{\circ} \mathrm{N}, 67.7231^{\circ} \mathrm{W}, 5-15 . V I I .2008$, R. P. Webster, mature hardwood forest, Lindgren funnel trap (1, NBM). Queens Co., Cranberry Lake P.N.A., $46.1125^{\circ} \mathrm{N}$, 65.6075W, 24.IV-5.V.2009, 5-12.V.2009, 12-21.V.2009, R. Webster \& M.-A. Giguère, old red oak forest, Lindgren funnel traps (17, AFC, NBM, RWC). 


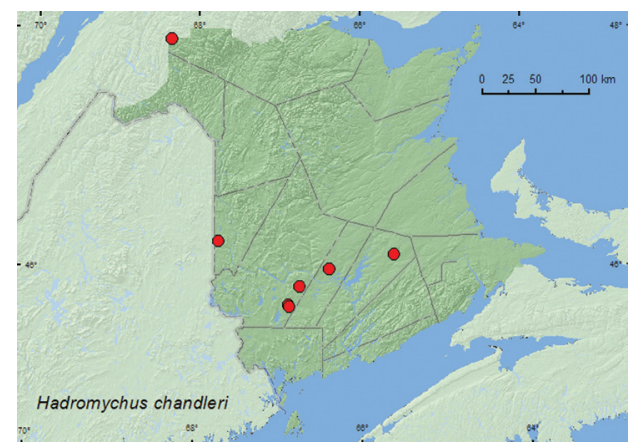

Map 7. Collection localities in New Brunswick, Canada of Hadromychus chandleri.

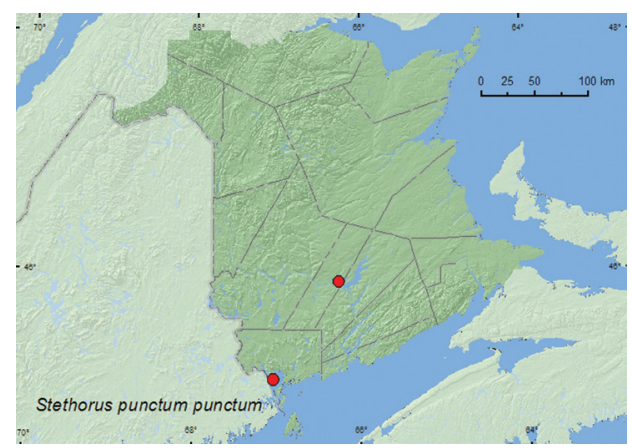

Map 9. Collection localities in New Brunswick, Canada of Stethorus punctatum punctatum.

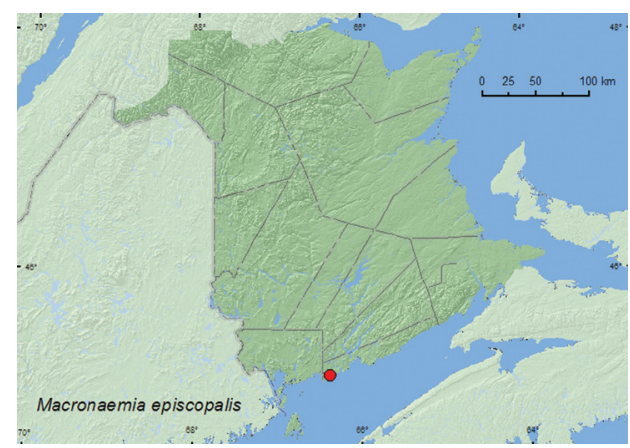

Map I I. Collection localities in New Brunswick, Canada of Macronaemia episcopalis.

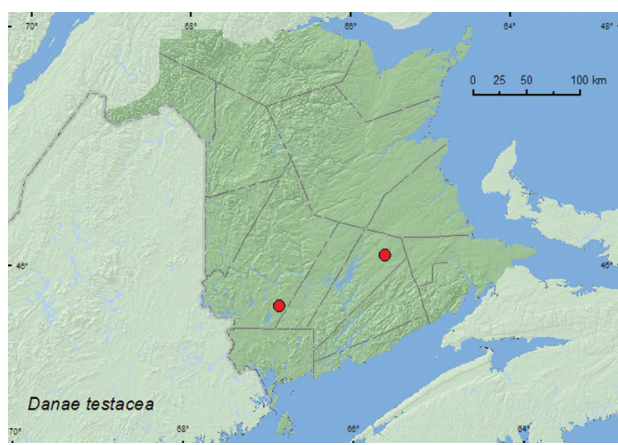

Map 8. Collection localities in New Brunswick, Canada of Danae testacea.

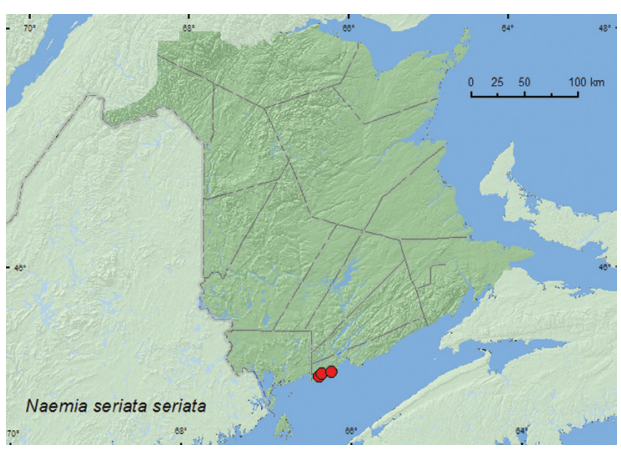

Map 10. Collection localities in New Brunswick, Canada of Naemia seriata seriata.

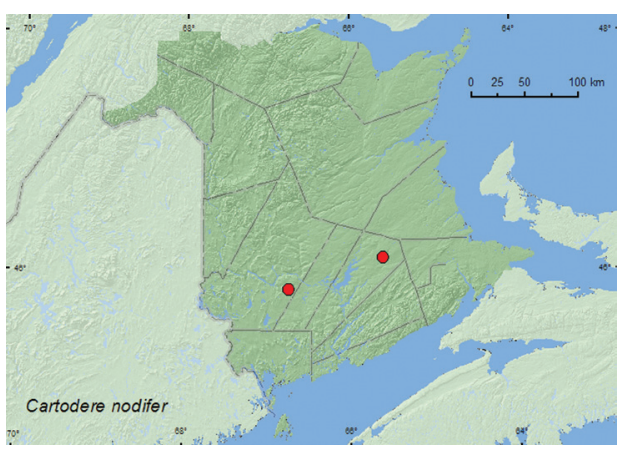

Map 12. Collection localities in New Brunswick, Canada of Cartodere nodifer.

Collection and habitat data. This species was captured in Lindgren funnel traps deployed in an old red oak forest and a mature hardwood forest. Adults were captured during April, May, and July. 
Distribution in Canada and Alaska. ON, QC, NB, NS (Bousquet 1991; Majka et al. 2009). This species was first reported from Nova Scotia and Atlantic Canada by Majka et al. (2009).

\section{Enicmus fictus Fall, 1899**}

http://species-id.net/wiki/Enicmus_fictus

Map 15

Material examined. New Brunswick, York Co., Charters Settlement, $45.8395^{\circ} \mathrm{N}$, $66.7391^{\circ} \mathrm{W}, 27$. VI.2007, R. P. Webster, mixed forest, u.v. light (1 AFC); same locality, habitat, and collector, 23.IV.2008, 9.V.2008, collected during aerial flight 15:00 to 18:00 h (2, RWC); same locality data and collector, 30.IX.2007, 11.X.2007, mixed forest, in decaying (mouldy) corncobs and cornhusks (2, RWC).

Collection and habitat data. This species is often found in stored products and has been collected from grass clippings (Hatch 1962; Bousquet 1990). In New Brunswick, specimens were collected from decaying (moldy) corncobs and cornhusks, at an ultraviolet light, and with an aerial net during an evening flight. Adults were captured during April, May, June, September, and October.

Distribution in Canada and Alaska. AK, NT, BC, AB, SK, MB, ON, QC, NB, NF (Bousquet 1991; Majka et al. 2009). This species was newly recorded from Newfoundland and Atlantic Canada by Majka et al. (2009).

\section{Encimus histrio Joy and Tomlin, 1910}

http://species-id.net/wiki/Encimus_histrio

Map 16

Material examined. New Brunswick, York Co., Marysville, $45.9750^{\circ} \mathrm{N}, 66.5700^{\circ} \mathrm{W}$, 22.VI.2007, S. Makepeace \& R. Webster, from nest material (remains of squirrel, various birds, bones, and insect parts) of barred owl in nest box (2, RWC).

Collection and habitat data. Two individuals of this adventive Palaearctic species were collected from nest material from a barred owl (Strix varia Barton) nest box during June. In the Palaearctic, this species has been found in damp or moldy straw, hay, grass cuttings and vegetable refuse (Hinton 1945).

Distribution in Canada and Alaska. NB, NS (Majka et al. 2009). This species was first reported from North America by Majka et al. (2009) from Sydney, Nova Scotia. 
Lathridius minutus (Linnaeus, 1767)

http://species-id.net/wiki/Lathridius_minutus

Map 17

Material examined. New Brunswick, Carleton Co., Jackson Falls, Bell Forest, $46.2200^{\circ} \mathrm{N}, 67.7231^{\circ} \mathrm{W}, 31 . I I I .2005$, R. P. Webster, mature hardwood forest, under bark of standing dead sugar maple (9, RWC); same locality and habitat data, 2328.IV.2009, R. Webster \& M.-A. Giguère, mature hardwood forest, Lindgren funnel traps (2, AFC, RWC). Kings Co., Belle Isle (Bellisle Creek), 18.II.1981, (no collector given) from bulk milk tank (1, AFC).

Collection and habitat data. In New Brunswick, this adventive Palaearctic species was collected from under bark of a large, standing, dead sugar maple, from a bulk milk tank, and from Lindgren funnel traps deployed in a mature hardwood forest. Adults were captured during February, late March, and April. This species is commonly associated with stored products (Bousquet 1990). Majka et al. (2009) provide additional details on the habitat associations, bionomics, and timeline of the introduction of this species in North America.

Distribution in Canada and Alaska. BC, AB, SK, MB, NB, PE, NS, NF (Bousquet 1991; Majka et al. 2009).

Stephostethus productus Rosenhauer, 1856***

http://species-id.net/wiki/Stephostethus_productus

Map 18

Material examined. Canada, New Brunswick, York Co., $15 \mathrm{~km}$ W of Tracy off Rt. $645,45.6848^{\circ} \mathrm{N}, 66.8821^{\circ} \mathrm{W}, 8-15 . V I .2009$, R. Webster \& M.-A. Giguère, old red pine forest, Lindgren funnel trap (1, RWC).

Collection and habitat data. One individual of this Palaearctic species was captured in a Lindgren funnel trap in an old red pine forest.

Distribution in Canada and Alaska. NB (new Canadian record). Downie and Arnett (1996) reported this adventive Palaearctic species from the state of New York with a "?", indicating that the record was questionable. We are not aware of any other records of this species for North America.

\section{Subfamily Corticariinae Curtis, 1829}

Corticaria elongata (Gyllenhal, 1827)

http://species-id.net/wiki/Corticaria_elongata

Map 19

Material examined. New Brunswick, Kings Co., Sussex, 18.IX.1981, (no collector given) from skim milk powder (2, AFC). 


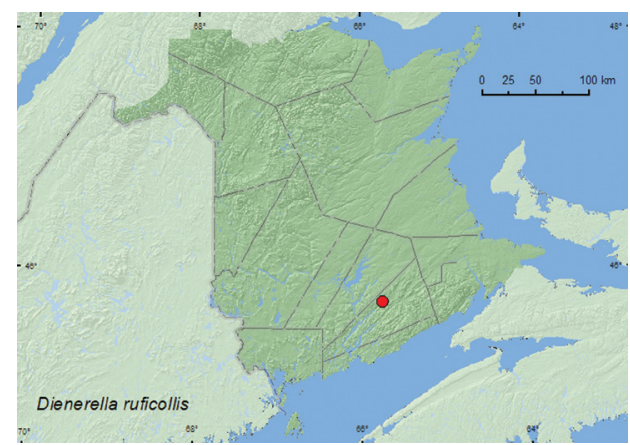

Map 13. Collection localities in New Brunswick, Canada of Dienerella ruficollis.

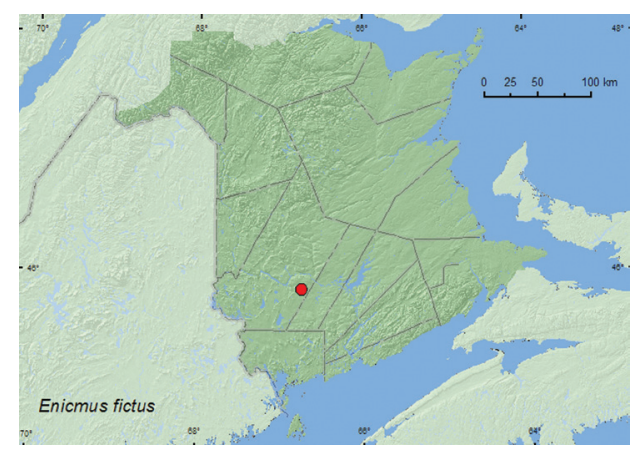

Map 15. Collection localities in New Brunswick, Canada of Enicmus fictus.

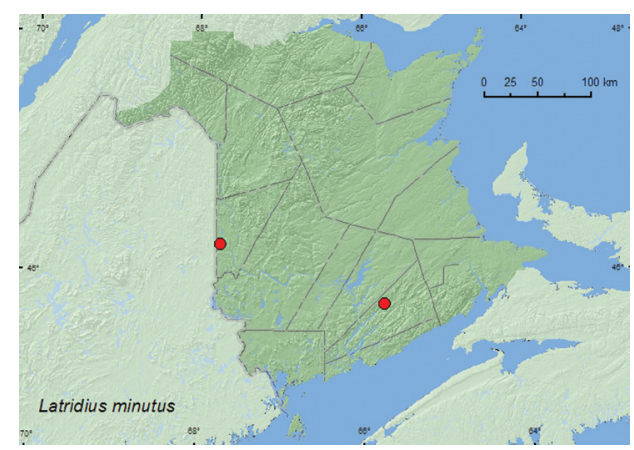

Map 17. Collection localities in New Brunswick, Canada of Lathridius minutus.

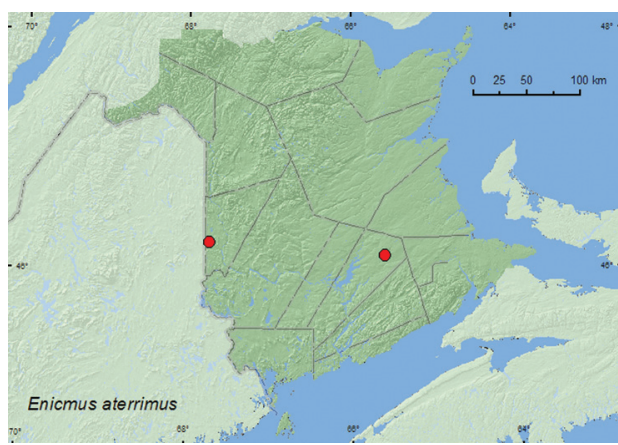

Map 14. Collection localities in New Brunswick, Canada of Enicmus aterrimus.

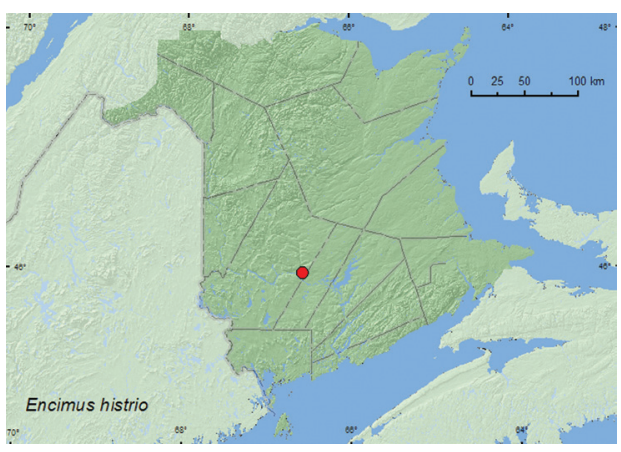

Map 16. Collection localities in New Brunswick, Canada of Enicmus histrio.

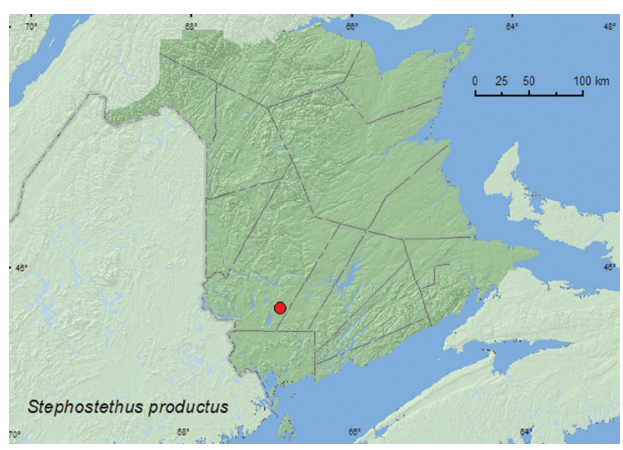

Map 18. Collection localities in New Brunswick, Canada of Stephostethus productus.

Collection and habitat data. Two individuals of this Holarctic or adventive Palaearctic species were collected from skim milk powder. In North America, this species is associated with stored products in grain elevators, warehouses, and feed mills (Hatch 1962; Bousquet 1990). 
Distribution in Canada and Alaska. NB, NS, NF (Majka et al. 2009). Majka et al. (2009) newly reported this for Canada on the basis of specimens from Newfoundland and Nova Scotia.

\section{Corticarina longipennis (LeConte, 1855)}

http://species-id.net/wiki/Corticarina_longipennis

Map 20

Material examined. New Brunswick, Queens Co., Cranberry Lake P.N.A., $46.1125^{\circ} \mathrm{N}, 65.6075^{\circ} \mathrm{W}, 21-27 . V .2009$, R. Webster \& M.-A. Giguère, old red oak forest, Lindgren funnel trap (1, RWC).

Collection and habitat data. One specimen was captured in a Lindgren funnel trap deployed in an old red oak forest. The adult was captured during May. Little is known about the habitat requirements of this species.

Distribution in Canada and Alaska. NB, NS (Majka et al. 2009). Majka et al. (2009) reported this species for the first time for Canada from a specimen collected in Beaver River, Nova Scotia.

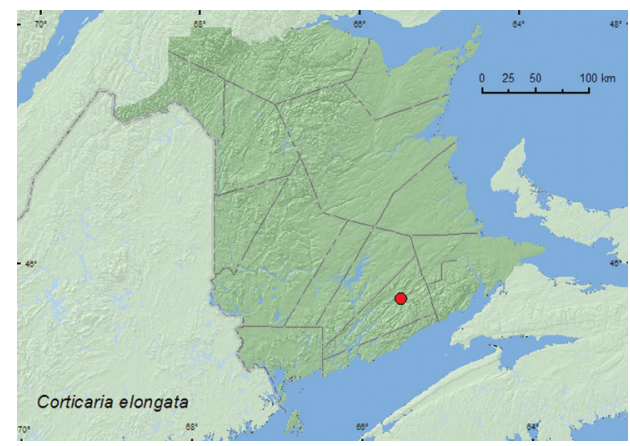

Map 19. Collection localities in New Brunswick, Canada of Corticaria elongata.

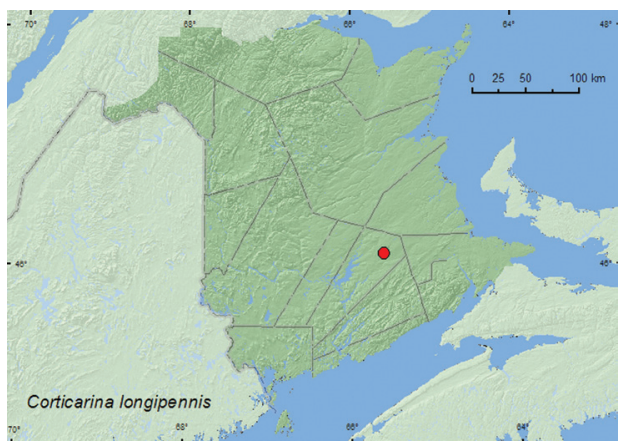

Map 20. Collection localities in New Brunswick, Canada of Corticarina longipennis

\section{Acknowledgments}

We thank Caroline Simpson (AFC) for editing this manuscript. An anonymous reviewer is thanked for many helpful comments that improved this manuscript. Anthony Davies and Yves Bousquet (Agriculture and Agri-Food Canada (CNC), Ottawa) are thanked for determining specimens and other invaluable assistance. Nichole Brawn, Kate Bredin, Katie Burgess, Marie-Andrée Giguère, Jim Edsall, Nancy Harn, Cory Hughes, Colin MacKay, Wayne MacKay, Jessica Price, Michelle Roy, Martin Turgeon, and Vincent Webster are thanked for technical assistance and collecting specimens. Natural Resources Canada, Canadian Forest Service; the Canadian Food Inspection Agency; and the USDA APHIS are thanked for funding the study on early detection 
of invasive cerambycids, which provided many specimens collected in Lindgren funnel traps. We thank the Canadian Wildlife Service for funding insect surveys at the Portobello Creek National Wildlife Area, the New Brunswick Environmental Trust Fund and the New Brunswick Wildlife Trust Fund for funding various insect surveys over the past 7 years, and the Meduxnekeag River Association for permission to sample beetles at the Meduxnekeag Valley Nature Preserve (which includes the Bell Forest). The New Brunswick Department of Natural Resources (Fish and Wildlife Branch) is thanked for issuing permits for sampling in the Protected Natural Areas and for providing logistical support.

\section{References}

Andrews FG (2002) Family 95 Latridiidae Erichson 1842. In: Arnett RH Jr, Thomas MC, Skelley PE, Frank JH (Eds) American Beetles. Volume 2. Polyphaga: Scarabaeoidea through Curculionoidea, CRC Press, Boca Raton, Florida, 395-398.

Bousquet $Y$ (1990) Beetles associated with stored products in Canada: an identification guide. Publication 1837, Research Branch, Agriculture Canada, Ottawa, Ontario.

Bousquet Y (1991) Family Lathridiidae: minute brown scavenger beetles. In: Bousquet Y (Ed) Checklist of Beetles of Canada and Alaska. Publication 1861/E, Agriculture Canada, Research Branch, Ottawa, Ontario, 239-241.

Bousquet Y, Leschen RAB (2002) Description of a new genus and species of Endomychidae (Coleoptera: Cucujoidea) from northern North America. The Coleopterists Bulletin 56(2): 291-298. doi: 10.1649/0010-065X(2002)056[0291:DOANGA]2.0.CO;2

Campbell JM (1991a) Family Cerylonidae: cerylonid beetles. In: Bousquet Y (Ed) Checklist of Beetles of Canada and Alaska. Publication 1861/E, Agriculture Canada, Research Branch, Ottawa, Ontario, 227.

Campbell JM (1991b) Family Endomychidae: handsome fungus beetles. In: Bousquet Y (Ed) Checklist of Beetles of Canada and Alaska. Publication 1861/E, Agriculture Canada, Research Branch, Ottawa, Ontario, 237-239.

Dearborn RG, Donahue CP (1993) An annotated list of insects collected and recorded by the Maine Forest Service: Order Coleoptera, Beetles. Technical Report 32. Maine Forest Service, Augusta, Maine, USA, $101 \mathrm{pp}$.

Downie NM, Arnett RH Jr (1996) The Beetles of Northeastern North America, Volumes 1 and 2. Sandhill Crane Press, Gainesville, Florida, 1721 pp.

Gordon RD (1985) The Coccinellidae (Coleoptera) of America north of Mexico. Journal of the New York Entomological Society 93: 1-912.

Habeck DH (2002a) Family 76, Brachypteridae Erichson 1845. In: Arnett RH Jr, Thomas MC, Skelley PE, Frank JH (Eds) American Beetles. Volume 2. Polyphaga: Scarabaeoidea through Curculionoidea, CRC Press, Boca Raton, Florida, 309-310.

Habeck DH (2002b) Family 77, Nitidulidae Latreille 1802. In: Arnett RH Jr, Thomas MC, Skelley PE, Frank JH (Eds) American Beetles. Volume 2. Polyphaga: Scarabaeoidea through Curculionoidea, CRC Press, Boca Raton, Florida, 311-315. 
Hatch MH (1962) The beetles of the Pacific Northwest. Part III: Pselaphidae and Diversicornia I. University of Washington Press, Seattle, Washington, 503 pp.

Hinton HE (1945) A monograph of the beetles associated with stored products. Vol. 1, British Museum (Natural History), London, UK, 443 pp.

Lawrence JF, Stephan K (1975) The North American Cerylonidae (Coleoptera: Clavicornia). Psyche 82: 131-166.

Lindgren BS (1983) A multiple funnel trap for scolytid beetles (Coleoptera). The Canadian Entomologist 115: 299-302. doi: 10.4039/Ent115299-3

Majka CG (2007) The Erotylidae and Endomychidae (Coleoptera: Cucujoidea) of the Maritime provinces of Canada: new records, zoogeography, and observations on beetle-fungi relationships and forest health. Zootaxa 1546: 39-50.

Majka CG (2009) Erratum: New Brunswick Endomychidae (Coleoptera). Zootaxa 2160: 68.

Majka CG, Cline AR (2006) Nitidulidae and Kateretidae (Coleoptera: Cucujoidea) of the Maritime provinces of Canada. I. New records from Nova Scotia and Prince Edward Island. The Canadian Entomologist 138: 314-332. doi: 10.4039/n05-070

Majka CG, Langor D (2011) The Cerylonidae (Coleoptera) of Atlantic Canada. Journal of the Acadian Entomological Society 7: 44-49.

Majka CG, Langor D, Rücker WH (2009) Latridiidae (Coleoptera) of the Atlantic Canada: new records, keys to identification, new synonyms, distribution, and zoogeography. The Canadian Entomologist 141: 317-370. doi: 10.4039/n09-050

Majka CG, McCorquodale DB (2006) The Coccinellidae (Coleoptera) of the Maritime provinces of Canada: new records, biogeographic notes, and conservation concerns. Zootaxa 1154: 49-68.

Majka CG, Robinson S (2009) Hyperaspis and Brachiacantha (Coleoptera: Coccinellidae): two poorly known genera of native lady beetles in the Maritime provinces. Journal of the Acadian Entomological Society 5: 3-11.

Majka CG, Webster R, Cline AR (2008) New records of Nitidulidae and Kateretidae (Coleoptera) from New Brunswick, Canada. Zookeys 2: 337-356. doi: 10.3897/zookeys.2.23

McNamara J (1991a) Family Coccinellidae: ladybird beetles. In: Bousquet Y (Ed) Checklist of Beetles of Canada and Alaska. Publication 1861/E, Agriculture Canada, Research Branch, Ottawa, Ontario, 229-237.

McNamara J (1991b) Family Nitidulidae: sap beetles. In: Bousquet Y (Ed) Checklist of Beetles of Canada and Alaska. Publication 1861/E, Agriculture Canada, Research Branch, Ottawa, Ontario, 214-219.

Thomas MC (2002) Family 91. Cerylonidae Billberg 1820. In: Arnett RH Jr., Thomas MC, SkelleyPE, Frank JH (Eds) American Beetles. Volume 2. Polyphaga: Scarabaeoidea through Curculionoidea, CRC Press, Boca Raton, Florida, 363-365.

Skelley PE, Leschen RA (2002) Family 92. Endomychidae Leach 1815. In: Arnett RH Jr., Thomas MC, Skelley PE, Frank JH (Eds) American Beetles. Volume 2. Polyphaga: Scarabaeoidea through Curculionoidea, CRC Press, Boca Raton, Florida, 366-370.

Webster RP, Klimaszewski J, Pelletier G, Savard K (2009) New Staphylinidae (Coleoptera) records with new collection data from New Brunswick, Canada. I. Aleocharinae. In: Majka 
CG, Klimaszewski J (Eds) Biodiversity, biosystematics, and ecology of Canadian Coleoptera II. ZooKeys 22: 171-248. doi: 10.3897/zookeys.22.152

Webster RP, Smetana A, Sweeney JD, DeMerchant I (in press) New Staphylinidae (Coleoptera) records with new collection data from New Brunswick and an addition to the fauna of Quebec: Staphylininae. In: Klimaszewski J, Anderson R (Eds) Biodiversity, Biosystematics and Ecology of Canadian Staphylinidae (Coleoptera) II. ZooKeys. 